\title{
THESIS
}

\section{LITTER REDUCTION BY PRESCRIBED BURNING CAN EXTEND DOWNY BROME CONTROL}

\author{
Submitted by \\ Kallie C. Kessler \\ Department of Bioagricultural Sciences and Pest Management
}

\author{
In partial fulfillment of the requirements \\ For the Degree of Master of Science \\ Colorado State University \\ Fort Collins, Colorado
}

Fall 2014

Master's Committee:

Advisor: K. George Beck

Scott J. Nissen

Paul J. Meiman 
Copyright by Kallie Christine Kessler 2014

All Rights Reserved 


\section{ABSTRACT \\ LITTER REDUCTION BY PRESCRIBED BURNING CAN EXTEND DOWNY BROME CONTROL}

Downy brome (Bromus tectorum L.) is a highly successful invasive species primarily because it fills an open niche in native plant communities. It also produces large amounts of litter over time. We hypothesized that removing accumulated litter with a prescribed burn before applying herbicides would improve herbicide efficacy, extending the duration of control. In January 2012, two downy brome infested sites were burned. In March 2012, post-emergent applications of glyphosate, imazapic, and tebuthiuron were made in a split-plot design. Aboveground biomass was collected at 6,18 and 27 months after treatment (MAT) to evaluate treatment effects. In non-burned areas, all herbicide treatments were similar to the control 27 MAT; however, burning combined with imazapic or tebuthiuron reduced downy brome biomass 27 MAT by $81 \% \pm 4.6 \mathrm{SE}$ and $84 \% \pm 19.3 \mathrm{SE}$, respectively. Remnant species responded positively to burning and herbicide treatments. Native cool season grass biomass increased after burning while native warm season grass biomass increased following tebuthiuron treatments. The impact of litter on imazapic and tebuthiuron availability was also evaluated. Herbicide interception increased in a linear relationship with increasing litter. For every $50 \mathrm{~g} \cdot \mathrm{m}^{-2}$ increase in litter there was a $7 \%$ increase in the amount of herbicide intercepted, meaning that $75 \%$ of the applied herbicide was intercepted by $360 \mathrm{~g} \cdot \mathrm{m}^{-2}$ of litter. A simulated rainfall event of $5 \mathrm{~mm}, 7$ days after application, removed a significant amount of herbicide. This indicates that at sites with surface litter, timely precipitation could be critical for herbicide efficacy; however, when burning was used to remove litter and was followed by herbicides with residual soil activity, 
downy brome control was extended. Due to downy brome's relatively short seed viability in the soil, extending herbicide efficacy to several years could help to reduce the soil seed bank. 


\section{ACKNOWLEDGEMENTS}

First and foremost, I would like to thank my advisor, Dr. K. George Beck, and committee members, Drs. Scott J. Nissen and Paul J. Meiman. All who have selflessly dedicated their time to guide and assist me on the path towards successful completion of my program. They challenged me to push my own personal limits and I am a better person and scientist because of them all. Additionally, I'm thankful to Dow AgroSciences for providing partial financial support and Vanelle Peterson for her guidance.

I look upon my time in the lab with Galen Brunk fondly. He taught me to be patient and remain strong no matter what life throws at you. He was a vital part of our program and we miss him dearly.

When my husband and I experienced the full wrath of Mother Nature, my pseudoadvisors, Drs. Scott J. Nissen and Sandra K. McDonald helped us literally knock down our walls and rebuild our lives. There are no words that adequately express our gratitude. During this difficult time, Rachel Asquith, our favorite Australian, kept us smiling through the entire process.

I would like to thank my fellow graduate students (Craig Beil, Cameron Douglass, Tom Getts, Darci Giacomini, Curtis Hildebrandt, Derek Sebastian, Christopher Van Horn, and Eric Westra). I appreciated their help, willingness to listen, advice and laughter.

I would like to thank my family. My Mom and Dad have always been my biggest supporters. They have shared my every struggle and celebrated in my every success. Lastly, I would like to thank my wonderfully kind, smart, and thoughtful husband. You are my every day support system and my future. My successes are our successes, may we relish in them equally. 


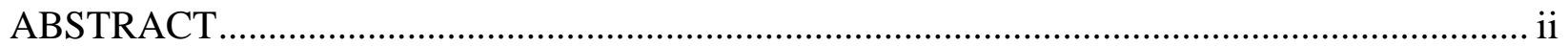

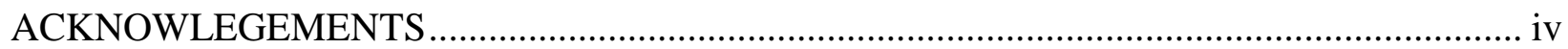

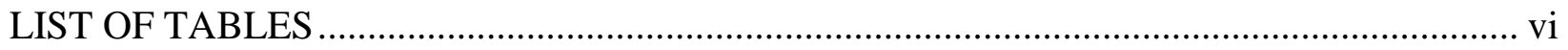

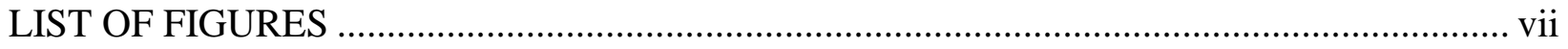

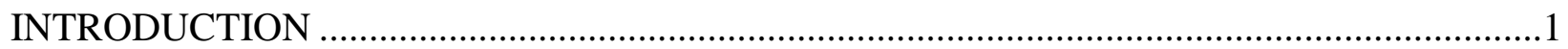

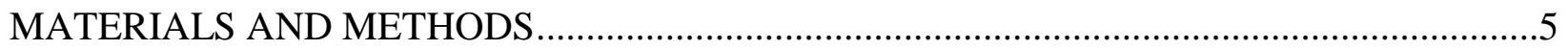

Integrating Prescribed Burning with Herbicides.............................................................

Herbicide Sorption to Litter .....................................................................................

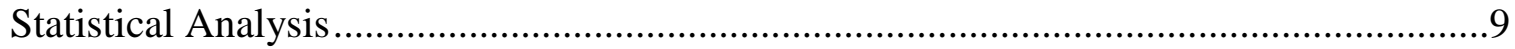

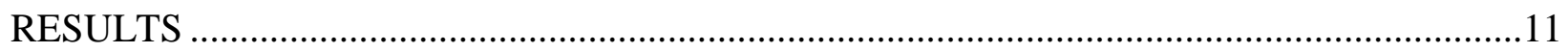

Integrating Prescribed Burning with Herbicides..............................................................11

Herbicide Sorption to Litter ..........................................................................................

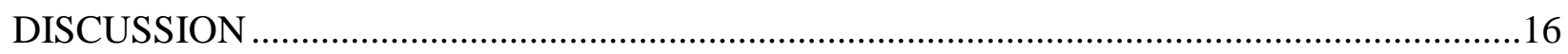

Integrating Prescribed Burning with Herbicides..............................................................16

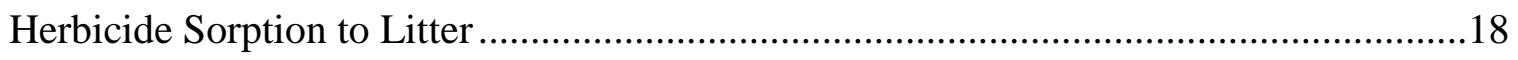

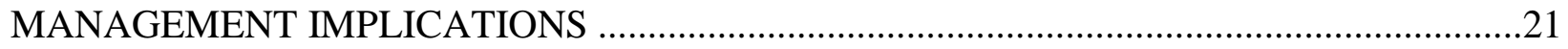

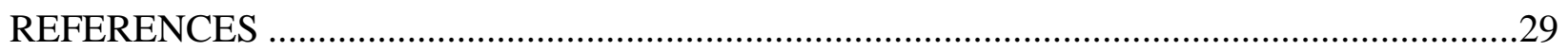

Appendix 1: Imazapic and Tebuthiuron Pre-emergent Dose Response Experiment........................35

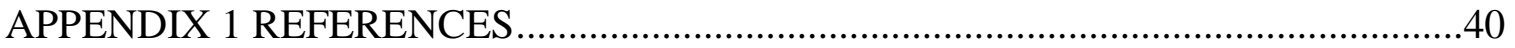

Appendix 2: Imazapic and Tebuthiuron Litter Interception Experiment......................................41

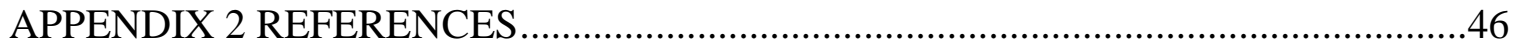




\section{LIST OF TABLES}

Table 1.1: Herbicide treatments, rates, formulas and sources 


\section{LIST OF FIGURES}

Figure 1.1: Monthly precipitation for Loveland, CO during the field experiment

Figure 1.2: Photograph of the three litter amounts used to examine herbicide interception by

surface litter

Figure 1.3: Downy brome biomass data collected 6, 18 and 27 months after herbicide treatments

were applied

Figure 1.4: Native perennial cool season grass biomass averaged over 6 and 18 months after

herbicide treatments were applied

Figure 1.5: Native forb biomass averaged over 6 and 18 months after herbicide treatments were

applied

Figure 1.6: Imazapic and tebuthiuron interception by surface litter, at three litter amounts .28

Figure A1.1: Response of downy brome dry weight to various imazapic and tebuthiuron doses,

28 days after treatment

Figure A2.1: The response of downy brome dry weight to imazapic and tebuthiuron when application occurred over various litter amounts, 28 days after treatment; combined with imazapic and tebuthiuron interception by surface litter, at five litter amounts 


\section{INTRODUCTION}

The invasive winter-annual grass, downy brome (Bromus tectorum L.), infests over 22 million ha in the western United States (Duncan et al. 2004). Rapid range expansion has been possible, in part, because there is no native winter-annual grass competitor, allowing downy brome to fill a unique, unoccupied niche (Mack 1981; Knapp 1996). This competitive advantage has had devastating ecological impacts; degrading the composition, structure and function of rangelands (Devine 1993; Duncan et al. 2004). Impacts include decreased native plant abundance, decreased forage quality, altered nutrient cycling; and increased wildfire frequency, and severity (Young et al. 1976; Morrow and Stahlman 1984; D'Antonio and Vitousek 1992; Knapp 1996; Young and Allen 1997).

Downy brome's ability to alter wildfire cycles is often cited as a reason it has been able to successfully outcompete native perennial grasses and forbs in many arid plant communities (Young et al. 1976; Melgoza et al. 1990; Young and Allen 1997). Seed germination begins in the late summer and individuals complete their life cycle by producing seed and senescing before many native species break winter dormancy (Young et al. 1969; D'Antonio and Vitousek 1992). For the remainder of the growing season, standing, senesced tissue serves as a fine fuel source. When wildfires are ignited in dense infestations, the extent and severity of these fires supersedes that of historic fires, thus, negatively impacting the native plant community (Brooks 2002; Link et al. 2006). Studies have shown that downy brome recovers to pre-fire levels within two seasons after fire, outcompeting desirable species (Young et al. 1976; Melgoza et al. 1990).

Conversely, fire has been used as a method to control winter annual grasses and stimulate the native plant community. Research shows that a fall or winter-timed burn, conducted when most desirable species are dormant, can provide short-term downy brome control by killing 
seedlings before they produce seed (Brooks 2002; DiTomaso et al. 2006). Decreased seedling survival has been attributed to decreased water availability and increased soil temperature fluctuations observed after surface litter is removed (Evans and Young 1970; Adair et al. 2008). In addition, burning can stimulate native grasses by removing years of accumulated surface litter (Knapp and Seastedt 1986; DiTomaso et al. 2006). Due to downy brome's ability to recover quickly after fires, prescribed burning is not recommended unless it is part of an integrated management plan where subsequent techniques are employed (Daubenmire 1968; Keeley and McGinnis 2007).

Perhaps the most common and effective subsequent management technique is the use of herbicides. Glyphosate, imazapic, and tebuthiuron have all shown efficacy in controlling downy brome, but the length of control that they provide is variable (Morrow et al. 1977; Beck et al. 1995; Whitson and Koch 1998; Blumenthal et al. 2006; Davison and Smith 2007; Morris et al. 2009; Elseroad and Rudd 2011; Mangold et al. 2013). Long-term control by glyphosate is unlikely due to a lack of residual soil activity; however, it's been reported to reduce downy brome during the season of application (Morrow et al. 1977; Beck et al. 1995; Whitson and Koch 1998). Due to foliar and residual soil activity, imazapic and tebuthiuron can control downy brome for at least two seasons. Imazapic has provided variable control, ranging from one to three seasons, and to our knowledge, only one study has reported control of downy brome by tebuthiuron (Davison and Smith 2007; Kyser et al. 2007; Duncan et al. 2009; Morris et al. 2009; Elseroad and Rudd 2011).

When designing a management plan, control is not the only objective. Ensuring management methods do not injure the remnant plant community will aid restoration success and prevent downy brome re-invasion (Blumenthal et al. 2006; Elseroad and Rudd 2011). 
Herbicides can have negative impacts on desirable perennial grasses and forbs if rate and timing are not appropriate. For example, glyphosate can injure remnant plants; however, after a falltimed application of $200 \mathrm{~g} \cdot \mathrm{ha}^{-1}$, minimal injury occurred to western wheatgrass (Pascopyrum smithii [Rydb.] À. Löve) and blue grama (Bouteloua gracilis [Willd. Ex Kunth] Lag. Ex Griffiths) (Lym and Kirby 1991). Previous studies have reported western wheatgrass and various needlegrass (Nassella spp.) injury after post-emergent (POST) imazapic applications; however, native forb tolerance is high (Beran et al. 1999; Shinn and Thill 2004; Kyser et al. 2007). Many native forbs are susceptible to tebuthiuron, but previous studies focusing on Artemisia L. spp. reduction reported the perennial grass community responded positively and both blue grama and western wheatgrass were highly tolerant (Whitson et al. 1988; Blumenthal et al. 2006).

The overall goal of a sequential management plan is to restore ecosystem composition, structure and function. Minimizing injury to the remnant plant community while providing adequate control duration can place the plant community on a trajectory towards recovery (Masters et al. 1996). Maximizing the duration of control is especially important when targeting downy brome as seed viability is short and under favorable conditions, nearly $100 \%$ of seed can germinate during one season (Harper et al. 1965; Young et al. 1969; Burnside et al. 1996). Strategies that take advantage of this weakness and decrease downy brome seed in the soil seed bank by providing control for three or more seasons should be pursued.

Recent publications have reported increased duration of downy brome and annual grass control when integrating prescribed burning and herbicides (Kyser et al. 2007; Sheley et al. 2007; Davies and Sheley 2011; Calo et al. 2012). Following burning with herbicides can increase control duration; however, it is unclear exactly why this occurs. Studies have reported 
that removing surface litter mechanically or through burning decreases seedling survival (Evans and Young 1970; Adair et al. 2008), but other studies have postulated that reducing surface litter increases herbicide efficacy by decreasing the amount of herbicide bound to litter (Washburn et al. 1999; DiTomaso et al. 2006). Despite much speculation, no quantitative studies have been conducted examining how surface litter interacts with herbicides used to control downy brome. We evaluated the effectiveness of integrating burning with glyphosate, imazapic, and tebuthiuron for downy brome management and the recovery of the remnant plant community in foothills grasslands infested with downy brome. In addition, we conducted laboratory experiments to quantify herbicide interception by litter and the subsequent impact of rainfall on herbicide desorption. 


\section{MATERIALS AND METHODS}

\section{Integrating Prescribed Burning with Herbicides}

Site Description. The field study was conducted at two sites near Loveland, Colorado from January, 2012 to June, 2014. Both the North and South study sites were located in an 889 ha Larimer County Property, Devil's Backbone Open Space (lat 40²8’24’N, long $\left.105^{\circ} 11^{\prime} 15^{\prime \prime} \mathrm{W}\right)$ in foothills grasslands on the western edge of the short-grass steppe. Elevation was approximately $1700 \mathrm{~m}$ and both studies were on southwestern facing slopes. At the beginning of the experiment, downy brome dominated the sites. A remnant plant community composed primarily of western wheatgrass and blue grama still persisted. The soil was classified as a Haplustoll, with cobbly to stony colluvium (USDA-NRCS 2014). The depth to paralithic bedrock is estimated to be between 25 and $100 \mathrm{~cm}$ and the soils are well drained with low water storage availability (USDA-NRCS 2014). Composite soil samples were collected from the top $20 \mathrm{~cm}$ of soil at each location and air dried for $24 \mathrm{~h}$ before sending subsamples to a private lab for analysis (Ward Laboratories, Inc., Kearney, NE). Soils analysis indicated that the North site had slightly higher organic matter $(\mathrm{OM})$ compared to the South site, $3.5 \% \pm 0.1$ and $2.9 \% \pm 0.3$ (mean $\pm \mathrm{SE}$ ), respectively. The $\mathrm{pH}$ at both sites was $6.2 \pm 0.1$ and the cation-exchange capacity

(CEC, meq $100 \mathrm{~g}^{-1}$ ) was $11.6 \pm 0.4$. The soils were classified as loam, with $46 \% \pm 0.7$ sand, $36 \% \pm 0.8$ silt and $18 \% \pm 0.4$ clay

Precipitation data were obtained from a weather station operated by Northern Colorado Water Conservancy District. Average yearly precipitation between 2001 and 2011 was 360 mm (NCWCD 2014). In 2012, a severe drought reduced annual precipitation to $172 \mathrm{~mm}$, half of the 11-yr average (NCWCD 2014). Annual precipitation in 2013 was $428 \mathrm{~mm}$ due to a significant rainfall event resulting in $183 \mathrm{~mm}$ of rainfall in September (Fig. 1) (NCWCD 2014). 
Experimental Design and Measurements. The experiment was a split-plot design with burning as the main plot factor and herbicide treatments as the subplot factor. At each site, a prescribed burn was conducted in January 2012 when downy brome was at the seedling growth stage. In March 2012, six herbicide treatments were applied when downy brome was at the twoto three-leaf growth stage (early post-emergent or EPOST). The herbicides included in this study were imazapic (Plateau), tebuthiuron + aminopyralid (Spike 80 DF + Milestone), and glyphosate (Rodeo). Herbicide treatment combinations and rates can be found in Table 1 . Aminopyralid was included in the tebuthiuron treatments as an experimental tank mix. Due to lack of downy brome control by aminopyralid in previous field studies and for the sake of brevity, this treatment will be referred to as tebuthiuron (Rinella et al. 2010). Imazapic treatments included $1.3 \% \mathrm{v} \cdot \mathrm{v}^{-1}$ methylated seed oil, while glyphosate and tebuthiuron treatments included $0.25 \% \mathrm{v} \cdot \mathrm{v}^{-1}$ non-ionic surfactant. All treatments were applied to $3 \mathrm{X} 9 \mathrm{~m}$ plots using a $\mathrm{CO}_{2}$ pressurized backpack sprayer with a $3 \mathrm{~m}$ spray boom and 6 flat fan $11002 \mathrm{VS}$ nozzles (TeeJet Tech, Wheaton, IL). The backpack sprayer was pressurized to $206 \mathrm{kPa}$ and calibrated to apply $187 \mathrm{~L} \cdot \mathrm{ha}^{-1}$.

To evaluate treatment effects, biomass was collected 6,18 and 27 months after treatment (MAT). Biomass was collected by harvesting two randomly placed, $0.5 \mathrm{~m}^{2}$ quadrats, on the right side of each plot, 6 MAT. All aboveground biomass was clipped and sorted into the following categories: downy brome, western wheatgrass, blue grama, sand dropseed (Sporobolus cryptandrus [Torr.] A. Gray), needle and thread (Hesperostipa comata [Trin. \& Rupr.] Barkworth), green needlegrass (Nassella viridula [Trin.] Barkworth) and native forbs. In addition, surface litter in each quadrat was collected. The same procedure was repeated 18 MAT, collecting biomass on the left side of each plot and 27 MAT, downy brome biomass was 
collected by placing the quadrats in the middle of each plot. All biomass samples were bagged and dried in a $60 \mathrm{C}$ oven for $72 \mathrm{~h}$ before obtaining dry weights.

\section{Herbicide Sorption to Litter}

Litter Collection. Litter was collected adjacent to the North study area, outside of the prescribed burn area in September, 2012. Dead vegetation was raked from the soil surface and placed in large plastic containers. These containers were then stored at room temperature (16 C to $24 \mathrm{C}$ ) and allowed to dry for several months before use. Litter composition could not be identified due to stem decomposition; however, litter was collected from the same plant community type in which the field experiment was conducted. Prior to use in experiments, the litter was sieved to remove soil and only shoot segments between 20 and $200 \mathrm{~mm}$ in length were included.

Interception. In all laboratory experiments, 45 X 205 X $205 \mathrm{~mm}$ metal pans were used to capture herbicide and rainfall. To quantify herbicide interception by litter, $250 \mathrm{ml}$ of methanol were poured into the metal pans and a $5 \mathrm{~mm}$ wire mesh screen was placed on top of the pan. Litter amounts of 120, 240, and $360 \mathrm{~g} \cdot \mathrm{m}^{-2}$ were spread evenly on top of the screen (Fig. 2). To determine the total quantity of herbicide applied, a metal pan with an empty screen was included as a control. Imazapic and tebuthiuron were applied at the same rates used in the field study (Table 1) with an overhead track spray chamber (DeVries Manufacturing Corp, Hollandale, MN) equipped with a single flat fan 8002E nozzle, calibrated to apply $187 \mathrm{~L} \cdot \mathrm{ha}^{-1}$ at $172 \mathrm{kPa}$ (TeeJet Tech). After herbicide application, a $10 \mathrm{~mL}$ aliquot was collected from the herbicide/methanol mixture from the bottom of each metal pan and stored at $-20 \mathrm{C}$ for analysis. There were four replicates per treatment and the entire experiment was repeated. 
Desorption. The largest amount of litter, $360 \mathrm{~g} \cdot \mathrm{m}^{-2}$, was spread evenly on top of a screen and placed over a metal pan containing $250 \mathrm{ml}$ of methanol. Imazapic and tebuthiuron were applied following the same procedure previously described. After herbicide application, the treated litter and screen were removed from the pan and maintained at $10 \mathrm{C}$ with $125 \mathrm{~W}$ fluorescent light exposure for $11 \mathrm{~h} \cdot \mathrm{d}^{-1}$. After a $7 \mathrm{~d}$ period, the treated litter (still on the screens) was placed over clean pans and we simulated rainfall by applying water using the same overhead track spray chamber. Rainfall amounts of 5 and $15 \mathrm{~mm}$ were applied using an 8004E nozzle traveling at $1.2 \mathrm{~km} \cdot \mathrm{h}^{-1}$. After rainfall, the total water volume captured in the metal pan was measured and a $10 \mathrm{~mL}$ aliquot of the herbicide/water mixture was collected and stored at $-20 \mathrm{C}$ for analysis. Herbicide still sorbed to litter was desorbed by cutting litter into $3 \mathrm{~cm}$ segments, placing segments in a $950 \mathrm{ml}$ glass jar containing $300 \mathrm{~mL}$ of methanol and agitating with a table shaker for $8 \mathrm{~h}$. After agitation, the litter and methanol were poured over a $90 \mathrm{~mm}$ filter placed in a Buchner funnel and drawn through the filter by a vacuum aspirator. The litter and filter were rinsed with an additional $200 \mathrm{~mL}$ of methanol and total methanol volume was recorded to account for any evaporation. Herbicide/methanol samples were stored at $-20 \mathrm{C}$ until they were analyzed using high-performance liquid chromatography (HPLC).

\section{HPLC Analysis.}

Interception. The herbicide interception samples were prepared by evaporating $2 \mathrm{~mL}$ of the herbicide/methanol sample to dryness, reconstituting in $1 \mathrm{~mL}$ of $10 \%$ acetonitrile and $0.5 \%$ phosphoric acid in HPLC grade water (mobile phase 1) and vortexing for $10 \mathrm{~s}$. Final sample preparation is described below.

Desorption. The herbicide/water samples collected from the rainfall portion of the experiment were prepared by transferring $0.5 \mathrm{~mL}$ to a $0.45 \mu \mathrm{m}$ nylon filter inserted into a $2 \mathrm{~mL}$ 
centrifuge tube. Tubes were centrifuged at $18800 \mathrm{X}$ g for $5 \mathrm{~min}$ (Sorvel Legend Micro 21, Thermo Fisher Scientific, Waltham, MA). The filtrate was transferred to a $1.5 \mathrm{~mL}$ HPLC vial and was analyzed by HPLC (Hitachi L-7100, Schaumburg, IL).

To prepare herbicide/methanol samples from the litter extraction, we filtered $10 \mathrm{~mL}$ of the methanol extract through a $0.45 \mu \mathrm{m}$ Teflon filter inserted into a $50 \mathrm{~mL}$ centrifuge tube and centrifuged at $25000 \mathrm{Xg}$ for $20 \mathrm{~m}$ (Sorvall Legend XT Centrifuge, Thermo Fisher Scientific). After centrifuging, samples were evaporated to dryness in a Rapid Vap set to 45 C (Labconco, Kansas City, MO). Samples were reconstituted in $1 \mathrm{~mL}$ of mobile phase 1, and vortexed for 10 s. Final sample preparation followed the method previously described.

HPLC Analysis. The herbicide concentration in each prepared sample was determined by HPLC coupled with UV detection (Hitachi L-7100). Herbicides were separated on a Zorbax RX C8 4.6 mm X $250 \mathrm{~mm}$ column (Agilent Technologies, Santa Clara, CA) by transitioning the mobile phase from $10 \%$ acetonitrile to $60 \%$ acetonitrile over a $20 \mathrm{~m}$ period. The injection volume was $500 \mu \mathrm{L}$ and the UV detector was set at $250 \mathrm{~nm}$. Imazapic and tebuthiuron were detected at retention times of 8.98 and 10.92 min, respectively. Herbicide concentration was determined by comparison to a standard curve ranging between 0.05 and $10 \mu \mathrm{g} \cdot \mathrm{mL}^{-1}$.

\section{Statistical Analysis}

Integrating Prescribed Burning with Herbicides. To determine differences between treatments, repeated measures analysis of variance (ANOVA) using the PROC MIXED method in SAS 9.3 was used (SAS Institute 2010). To meet the normality and homoscedasticity assumptions of ANOVA, we transformed dry biomass data for each species using either a $\log \left(\mathrm{x}^{\prime}\right.$ $=\log [\mathrm{x}+1])$ or square root transformation $\left(\left[\mathrm{x}^{\prime}=\mathrm{x}+0.5\right]^{0.5}\right)$. Downy brome was analyzed separately from other species. All other species were combined into appropriate functional 
groups (native cool season perennial grasses, native warm season perennial grasses, and native forbs). Factors included in the model were site, burning, herbicide treatment, year and all possible interactions. The random factor was site by burning within block and year was defined as the repeated measure. Interactions and main effects with p-values $\leq 0.05$ were considered significant. Significant interactions were further analyzed by Fisher's Protected LSD tests. Means and SE presented in figures are the original, non-transformed data.

Imazapic and Tebuthiuron Sorption to Litter. Interception data were analyzed using linear regression in PROC REG and ANOVA was used to analyze sorption data in PROC GLM (SAS Institute 2010). When analyzing interception data, herbicide and litter amount were factors. Herbicide and rainfall amount were factors when analyzing sorption data. To ensure laboratory methods resulted in a high herbicide recovery rates, a mass balance was conducted and any experiment with greater than $10 \%$ herbicide loss was disregarded. After failing to reject the null hypothesis of a Levene's test that experimental variances are equal, replicated experiments were combined. 


\section{RESULTS}

\section{Integrating Prescribed Burning with Herbicides}

Downy Brome Response. Three-way interactions of location, burning, and year ( $\mathrm{P}<$ 0.0001); location, herbicide treatment, and year $(\mathrm{P}=0.0341)$; and burning, herbicide treatment, and year $(\mathrm{P}=0.0160)$ were significant. The burning, herbicide treatment and year interaction specifically refers to our study objectives, and thus is the focus of this section. Due to the burning, herbicide treatment, and year interaction, downy brome biomass for each herbicide treatment is displayed according to the three harvest dates; 6, 18, and 27 MAT (Fig 3). Unless specifically stated, mean comparisons refer back to the non-burned control in the same harvest date.

Compared to control plots, all herbicide treatments significantly decreased downy brome biomass 6 MAT, regardless of the main plot factor (burned vs non-burned) (Fig. 3). The tebuthiuron alone treatment was the only herbicide treatment for which downy brome biomass in the burned plots was lower than the non-burned plots. With this one exception, there was no significant advantage, in terms of herbicide efficacy 6 MAT, from removing surface litter with a prescribed burn. All other herbicide treatments decreased downy brome biomass by at least $92 \%$ \pm 1.0 .

By the second harvest (18 MAT), there was a difference in downy brome biomass between the burned and non-burned controls, indicating that burning alone could decrease downy brome biomass, at least in the short term (Fig. 3). At this harvest date, glyphosate treatments were similar to the control when comparing within burned and non-burned main plots. Imazapic and tebuthiuron have residual soil activity, so these treatments were still highly effective when compared to the non-burned, control. Downy brome biomass was lowest in 
burned areas compared to non-burned areas for the control and all herbicide treatments except for tebuthiuron, 18 MAT. In burned plots, imazapic and tebuthiuron reduced downy brome biomass by 96 to $99 \% \pm 4.1$; however, the same herbicide treatments were less effective in nonburned plots, reducing downy brome biomass by only 59 to $85 \% \pm 11.5,18$ MAT.

The widespread effect of burning that we observed 18 MAT was no longer evident 27 MAT. Downy brome biomass was similar in the controls and the glyphosate only plots for burned and non-burned treatments, 27 MAT (Fig 3). In the non-burned areas, all herbicide treatments had the same downy brome biomass as the controls, indicating that in this study, herbicides alone could be expected to provide only two season of acceptable downy brome control. In the burned main plots, all herbicide treatments, except for glyphosate and tebuthiuron + glyphosate were still providing a reduction in downy brome biomass. Imazapic and tebuthiuron treatments decreased downy brome biomass by $81 \% \pm 4.6$ and $84 \% \pm 19.3$, respectively, in the burned main plots, 27 MAT. At the end of the three-season evaluation period, imazapic and tebuthiuron combined with burning resulted in the greatest reduction in downy brome biomass.

Perennial Grass Response. The plant community at this location is dominated by native cool and warm season perennial grasses. The cool season grasses were western wheatgrass, green needlegrass and needle and thread, with western wheatgrass accounting for over $98 \%$ of the total desirable cool season grass biomass. There were two native warm season bunch grasses, blue grama and sand dropseed. Blue grama was the dominant species of this functional group, representing $81 \%$ of the total warm season grass biomass.

These two functional groups responded differently to the prescribed burn conducted in January of 2012. Averaged across other factors, burning did not influence warm season grass 
biomass $(P=0.8743)$. Site by year $(P=0.0088)$ and burning by herbicide treatment $(P=0.0250$; Fig. 4) interactions affected cool season grass biomass, but no other interactions were significant. Cool season grass biomass was lowest in the control subplot of the non-burned main plot and there was no difference among herbicide treatments in the burned main plot.

In contrast, herbicide treatments appeared to cause a shift in warm season grass biomass at each site as indicated by a significant herbicide treatment by site interaction $(\mathrm{P}=0.0009)$. Warm season grass biomass was slightly greater at the South site compared to the North. At the South site, tebuthiuron was the only herbicide treatment with greater warm season grass biomass than the control $\left(89 \mathrm{~g} \cdot \mathrm{m}^{-2} \pm 13.1\right.$, vs $\left.65 \mathrm{~g} \cdot \mathrm{m}^{-2} \pm 11.9, \mathrm{P}=0.0208\right)$. At the North site, there was more warm season grass biomass in the glyphosate $\left(45.3 \mathrm{~g} \cdot \mathrm{m}^{-2} \pm 6.4, \mathrm{P}=0.0108\right)$, imazapic + glyphosate $\left(54 \mathrm{~g} \cdot \mathrm{m}^{-2} \pm 7.5, \mathrm{P}=0.0009\right)$, tebuthiuron $\left(58.1 \mathrm{~g} \cdot \mathrm{m}^{-2} \pm 7.6, \mathrm{P}=0.0001\right)$ and tebuthiuron + glyphosate $\left(47 \mathrm{~g} \cdot \mathrm{m}^{-2} \pm 7.2, \mathrm{P}=0.0088\right)$ treatments compared to the control (27 $\left.\mathrm{g} \cdot \mathrm{m}^{-2} \pm 5.3\right)$. There were no other significant interactions, including herbicide by burning $(\mathrm{P}=$ 0.1496), indicating that there was no warm season grass biomass reduction when integrating these two strategies.

Native Forb Response. Native forbs were highly variable so no individual species data were collected; however, the dominant species were tarragon (Artemisia dracunculus L.), prairie sagewort (Artemisia frigida Willd.), scarlet globemallow (Sphaeralcea coccinea [Nutt.] Rydb.), and Cuman ragweed (Ambrosia psilostachya DC.). Forb biomass was affected by both burning and herbicide treatment, as indicated by the interaction of these two factors $(\mathrm{P}=0.0031$; Fig. 5). No other interactions were significant. All herbicide treatments containing imazapic increased forb biomass when burned, and tebuthiuron reduced forb biomass in burned and unburned treatments, with the lowest forb biomass occurring in the burned main plots in treatments 
containing tebuthiuron. In addition, forb biomass varied by year $(\mathrm{P}=0.0014)$. Biomass was greatest during the second evaluation period, where rainfall was above the 11-year average (Fig. 1).

Litter. Monitoring the quantity of litter during the course of this research was important to understand the impact of the prescribed burn on litter and to determine the quantity of litter that was present for herbicide interception. We did not determine the amount of litter immediately following the prescribed burn, but six months after the herbicide applications the amount of litter in the burned study area was $30 \mathrm{~g} \cdot \mathrm{m}^{-2} \pm 5$, while in the non-burned study area, litter amount was 10 -fold greater $\left(300 \mathrm{~g} \cdot \mathrm{m}^{-2} \pm 14\right)$. Over the next 12 months $(18 \mathrm{MAT})$, the difference between litter amount in the burned and non-burned study area was much smaller. The amount of litter in the burned main plot had increased to $47 \mathrm{~g} \cdot \mathrm{m}^{-2} \pm 3$, while in the nonburned main plot litter had decreased to $194 \mathrm{~g} \cdot \mathrm{m}^{-2} \pm 8$. This decrease in litter was most likely due to differences in precipitation. In 2012, precipitation was half of the 11-year average, decreasing total biomass production (Fig. 1). The drop in litter biomass observed in 2013 is most likely due to a lack of vegetative productivity during 2012.

\section{Herbicide Sorption to Litter}

Interception. Herbicide interception was similar for imazapic and tebuthiuron $(\mathrm{P}=0.7373)$. There was a positive correlation between litter amount and herbicide interception for both herbicides $\left(R^{2}=0.8805, \mathrm{P}<0.0001\right)$ (Fig. 6). At the lowest litter amount, $120 \mathrm{~g} \cdot \mathrm{m}^{-2}$, $42.5 \% \pm 1.6$ of the herbicide was intercepted by the litter, while at the highest litter amount, 360 $\mathrm{g} \cdot \mathrm{m}^{-2}, 74.6 \% \pm 1.8$ of the herbicide was intercepted (Fig. 6). The highest litter amount was close to the amount of litter collected in the field in the non-burned main plot in 2012. Theoretically, our results indicate that only $25 \%$ of herbicide is immediately available after herbicide 
application due to interception and as surface litter increases by $50 \mathrm{~g} \cdot \mathrm{m}^{-2}$, herbicide interception increases by $7 \%$.

Desorption. Our results indicate that a significant amount of the herbicide intercepted by litter can be removed with a single rainfall event, even 7 days after the initial application. More imazapic desorbed from the litter than tebuthiuron following each rainfall event $(\mathrm{P}=0.0001)$ and more herbicide was removed with the larger rainfall amount $(\mathrm{P}=0.002)$. The interaction between herbicide and rainfall amount was not significant $(\mathrm{P}=0.7814)$. On average, rainfall removed $69.5 \% \pm 2.6$ and $59.5 \% \pm 2.6$ of the intercepted imazapic and tebuthiuron, respectively. The herbicide was not tightly bound to the litter and $57.5 \% \pm 2.6$ of the intercepted herbicide can be removed with as little as $5 \mathrm{~mm}$ of rainfall. However, when the rainfall amount was tripled (15 $\mathrm{mm}$ ), only $14.1 \% \pm 2.6$ more herbicide was desorbed. The methanol extractions we conducted to establish a mass balance for herbicide recovery suggested that somewhere between 15 and $25 \%$ of the herbicide is difficult to remove from litter and will be essentially non-available. 


\section{DISCUSSION}

\section{Integrating Prescribed Burning with Herbicides}

We found that burning alone decreased downy brome biomass for two seasons (Fig. 3); although, the effect of burning was not apparent until the second season due to a severe drought that occurred during the first growing season (Fig. 1). Sheley et al. (2007) also noted a decrease in winter annual grass biomass when comparing burned and non-burned plots, but due to the difficultly of replicating prescribed burns, no statistical analysis was conducted. There appear to be both short-term and long-term impacts associated with burning to decrease litter accumulation in downy brome infested sites. In the short-term, removing litter with a prescribed burn appears to favor the native plant community and makes it more difficult for downy brome to germinate and establish (Evans and Young 1970; Adair et al. 2008). On the other hand, numerous studies have determined that downy brome infested sites have increased fire frequency that negatively impacts the native community and tends to increase the downy brome density (Melgoza et al. 1990; D'Antonio and Vitousek 1992; DiTomaso et al. 2006). So a prescribed burn represents the first phase of an integrated program using the sequential application of different techniques for downy brome control.

In this study, our sequential techniques were a prescribed burn followed by herbicides. Imazapic and tebuthiuron have both foliar and residual soil activity causing decreased downy brome biomass for two seasons whether these herbicides were applied alone or used in combination with burning. The importance of soil activity is exemplified by our results using glyphosate alone. Glyphosate is highly effective in controlling downy brome when applied to the foliage, but it has no soil activity (Morrow et al. 1977; Beck et al. 1995; Whitson and Koch 1998; Senseman 2007). Therefore, downy brome control with glyphosate was only detectable 
during the first season (Fig. 3) and by 18 MAT downy brome biomass in plots treated with glyphosate alone was similar to the control.

We hypothesized that by using these sequential treatments we could extend downy brome control beyond using herbicides alone. Our results suggest herbicides with residual soil activity provided no more than two seasons of control when they were not part of an integrated management plan and this duration of control is similar to previous reports (Morris et al. 2009; Kyser et al. 2013).

Overall, downy brome biomass was lowest in plots where burning was integrated with imazapic and tebuthiuron treatments at the final harvest date (27 MAT), supporting our general hypothesis. Several other studies have reported longer downy brome control when integrating burning and herbicides (Kyser et al. 2007; Calo et al. 2012). In addition, increased herbicide efficacy following prescribed burning has also been observed in several studies where medusahead (Taeniatherum caput-medusae[L.] Nevski) was the target species (Kyser et al. 2007; Sheley et al. 2007; Davies and Sheley 2011).

Burning and herbicide treatments had only minor effects on the remnant plant community. Cool season grass biomass increased in response to burning, while warm season grass biomass increased after tebuthiuron treatment (Figs. 4). While no treatments decreased perennial grass biomass in our study, other studies have reported injury to perennial grasses following imazapic applications, especially as rate increased (Shinn and Thill 2004; Monaco et al. 2005). In our study, native forb biomass increased when imazapic was applied following a burn, but decreased in the tebuthiuron treatments, especially when combined with burning (Fig 5). Our results contradict a study evaluating forb response after imazapic application in sagebrush dominated sites, where a decrease in forb cover was reported (Davies and Sheley 
2011). Several other studies have reported that numerous forbs are tolerant to imazapic (Beran et al. 1999; Kyser et al. 2007; Kyser et al. 2013).

We did confirm that many forbs are susceptible to tebuthiuron. This was expected since most tebuthiuron research has been focused on forb control, especially Artemisa spp. (Whitson et al. 1988; Blumenthal et al. 2006). During the time span of this study, we found no evidence that integrating burning and herbicides decreased desirable native perennial grass biomass more than either method alone. Actually, none of the herbicide treatments we studied prevented the increase in cool season native perennial grass biomass in response to fire. Similar studies have reported that perennial grasses responded favorably to burning followed by imazapic (Sheley et al. 2007; Davies and Sheley 2011). As a result, land-managers should consider their remnant plant community when designing an integrated management plan to minimize injury to the native plant community and increase the probability of successful long-term restoration (Blumenthal et al. 2006).

\section{Herbicide Sorption to Litter}

After herbicide desorption by simulated rainfall, $20 \%$ of imazapic and $27 \%$ of tebuthiuron were still sorbed to the litter, suggesting that in the absence of litter, more herbicide would reach the soil, extending downy brome control. Numerous studies have reported longerterm annual grass control after litter removal compared to paired sites where litter is still present (Monaco et al. 2005; Kyser et al. 2007; Sheley et al. 2007; Davies and Sheley 2011; Calo et al. 2012). Due to the confounding effects of prescribed burning, such as decreases in soil moisture and increased soil temperature fluctuations, these studies only imply that herbicide sorption to litter may be decreasing duration of control (Evans and Young 1970). The results of our sorption experiments demonstrate that litter intercepted the vast majority of imazapic and tebuthiuron and 
that even after a sizeable precipitation event, a significant amount of herbicide remained sorbed to the litter. The amount of litter that we used to measure herbicide interception was similar to what we measured at our field sites; however, it does not represent the maximum litter amount that has been measured in an annual grass infestation. There are reports of litter that has accumulated up to $885 \mathrm{~g} \mathrm{~m}^{-2}$ (Ogle et al. 2003). Interception could approach $100 \%$ in these situations and without a timely rainfall event, downy brome could germinate and establish with no herbicide impacts. The variability in downy brome control provided by imazapic could be the result of herbicide interception combined with the lack of timely precipitation (Mangold et al. 2013).

Timing and amount of precipitation have been cited as primary reasons restoration efforts succeed or fail (Hardegree et al. 2012). From 2012 to 2014, precipitation varied greatly, affecting downy brome and litter biomass (Fig. 1 and 3). Downy brome biomass was low in 2012, doubled in 2013, and more than tripled by 2014 (Fig. 3). In 2012, litter amount was high in the non-burned study area, but less than $66 \%$ of litter remained in 2013 due to lack of precipitation the previous season. Fluctuations in litter and downy brome biomass due to precipitation have been reported previously and serve as reminder why generalizing about treatment impacts is so difficult (Uresk et al. 1979; Morris et al. 2009; Bansal et al. 2014). In September 2013, the Front Range of Colorado experienced some extreme weather that NOAA classified as a 1,000-year rainfall event. Our field sites received more precipitation during the month of September than the total precipitation received for all of 2012 (Fig. 1). This above normal precipitation resulted in a massive downy brome recruitment event and a significant increase in downy brome biomass in 2014. Herbicide treatments not combined with burning 
were no longer effective; however, herbicide treatments combined with burning were still providing a significant reduction in downy brome biomass.

Integrating burning with herbicides can provide longer and more consistent downy brome control; however, there is still much debate around which herbicide rates and timings are most efficacious (Kyser et al. 2007; Morris et al. 2009). Mangold et al. (2013) speculated that abiotic factors such a precipitation were responsible for much of the variability in the success of imazapic treatments. The results of our sorption and desorption experiments suggest a plausible explanation for why timely rainfall appears to be such a driving factor for success.

The goal of increasing the duration of control is based on the concept that due to downy brome's short seed viability, providing multiple seasons of control could drive down the soil seed bank, increasing long-term management success (Harper et al. 1965; Young et al. 1969; Burnside et al. 1996). There may be unintended consequences associated with the combination of burning and herbicides. Removing litter would make more of the herbicide immediately available in the soil solution; therefore, it is possible that desirable remnant or seeded species could be injured. Other studies have reported injury to desirable species as herbicide rate increases (Kyser et al. 2007; Morris et al. 2009); however, in our study, native forbs and native cool season perennial grasses responded favorably to imazapic while native warm season perennial grasses were unaffected (Fig. 4 and 5). Imazapic and tebuthiuron treatments increased cool season perennial grass biomass and tebuthiuron increased warm season perennial grass biomass but reduced forb biomass (Fig. 4 and 5). Nonetheless, caution should be taken when determining herbicide application rate, especially at low litter sites. It is likely that land managers will need to determine herbicide and application rate based on individual site characteristics and management objectives. 


\section{MANAGEMENT IMPLICATIONS}

When designing a restoration plan, land managers should consider their current plant community and subsequent land management objectives. In this study, glyphosate was only effective in the season following application, while imazapic and tebuthiuron controlled downy brome for two seasons in the non-burned study area and for at least three seasons in the burned study area. Using prescribed burning and herbicides in combination, as part of an integrated management plan, can cause functional group dynamics to change. Imazapic may shift the plant community by increasing native forb biomass, while tebuthiuron may shift the plant community to a grassland favoring warm season grasses with little forb diversity. Burning while desirable species are dormant may improve conditions for native grasses and reduce or eliminate conditions that favor downy brome. Our laboratory studies indicated that herbicides are intercepted by surface litter, but a significant amount of herbicide can be desorbed by a single precipitation event. Ultimately, herbicide interception by litter combined with the lack of a timely precipitation event may reduce the success of herbicide treatments if not integrated into a sequential management plan. 
Table 1.1: Herbicide treatments, rates, formulations and sources.

\begin{tabular}{|l|c|c|}
\hline \multicolumn{1}{|c|}{ Treatment } & $\begin{array}{c}\text { Rate } \\
\left(\mathrm{g} \cdot \mathrm{ha}^{-1}\right)\end{array}$ & Trade name \\
\hline Imazapic & $105 \mathrm{ai}$ & Plateau $^{1}$ \\
\hline Imazapic + glyphosate & $105 \mathrm{ai}+280 \mathrm{ae}$ & Plateau $^{1}+$ Rodeo $^{2}$ \\
\hline Tebuthiuron + aminopyralid & $420 \mathrm{ai}+91 \mathrm{ae}$ & ${\text { Spike } 80 \mathrm{DF}^{2}+\mathrm{Milestone}^{2}}^{2}$ \\
\hline $\begin{array}{l}\text { Tebuthiuron + aminopyralid }+ \\
\text { glyphosate }\end{array}$ & $420 \mathrm{ai}+91 \mathrm{ae}+280 \mathrm{ae}$ & $\begin{array}{c}\text { Spike } 80 \mathrm{DF}^{2}+\text { Milestone }^{2}+ \\
\text { Rodeo }^{2}\end{array}$ \\
\hline Glyphosate & $280 \mathrm{ae}$ & Rodeo $^{2}$ \\
\hline Control & - & - \\
\hline
\end{tabular}

${ }^{1}$ BASF Corp, Research Triangle Park, NC.

${ }^{2}$ Dow Agro Sciences LLC, Indianapolis, IN. 


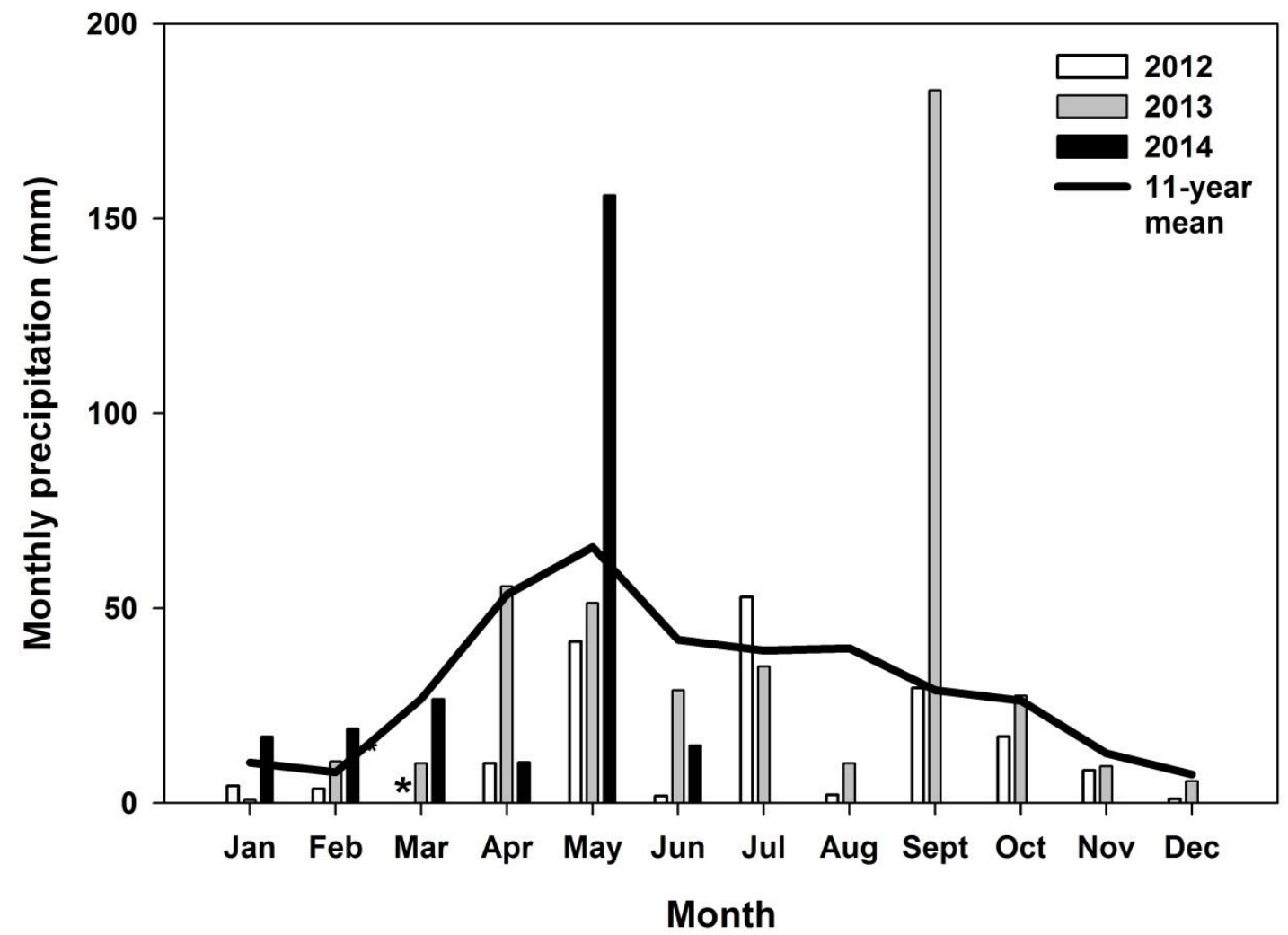

Figure 1.1: Monthly precipitation for Loveland, $\mathrm{CO}$ during the field experiment is depicted by shaded bars. These values are compared to the 11-year mean, depicted by the line (2001 - 2011). * In March, 2012 there was $0 \mathrm{~mm}$ precipitation. 


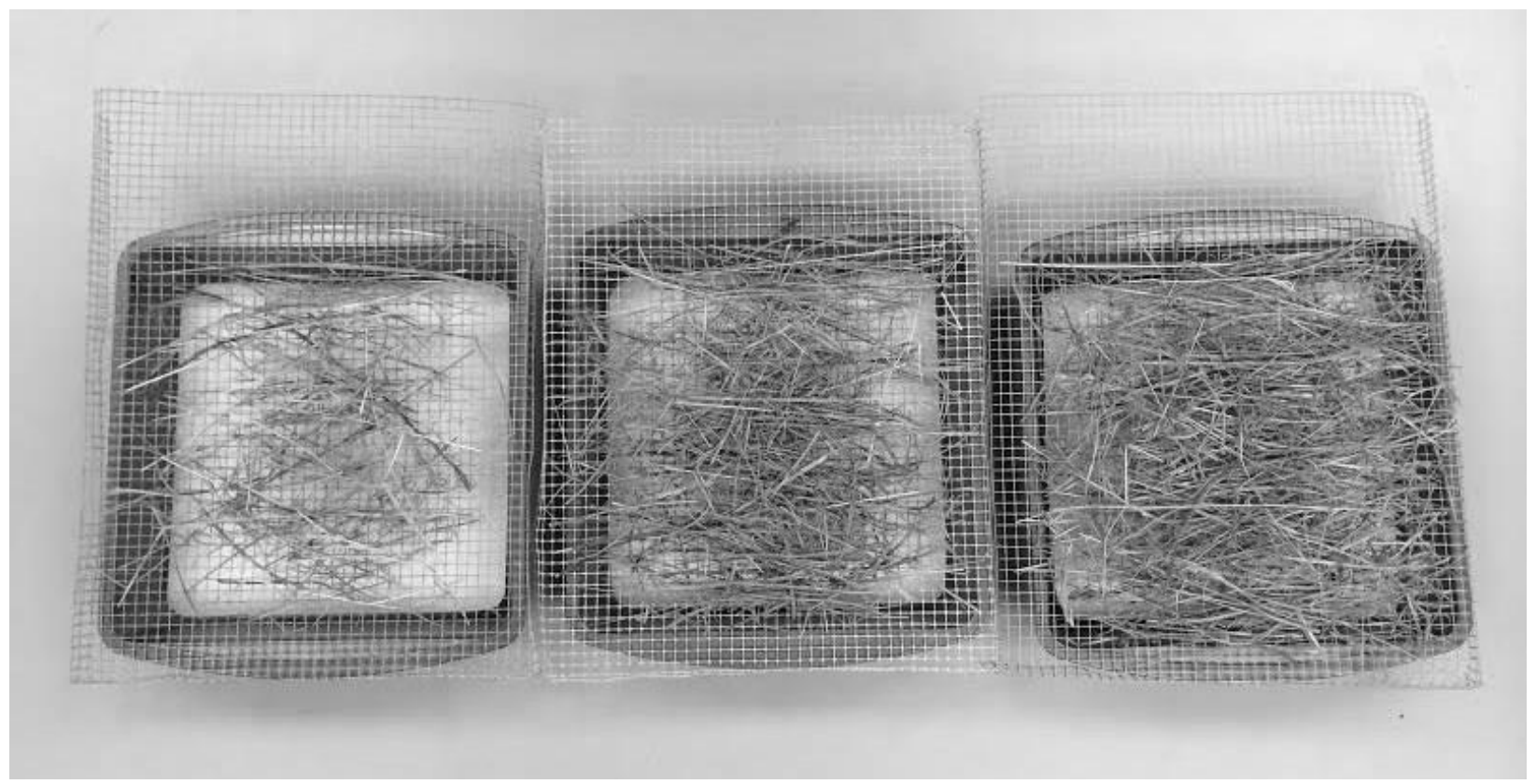

Figure 1.2: Three litter amounts were placed on top of a wire mesh screen and placed over a metal pan to examine herbicide interception by surface litter $\left(120,240\right.$, and $360 \mathrm{~g} \cdot \mathrm{m}^{-2} \mathrm{from}$ left to right). Surface litter was collected from a downy brome infestation with a remnant native plant understory in Devil's Backbone Open Space, located in Larimer County, CO. 


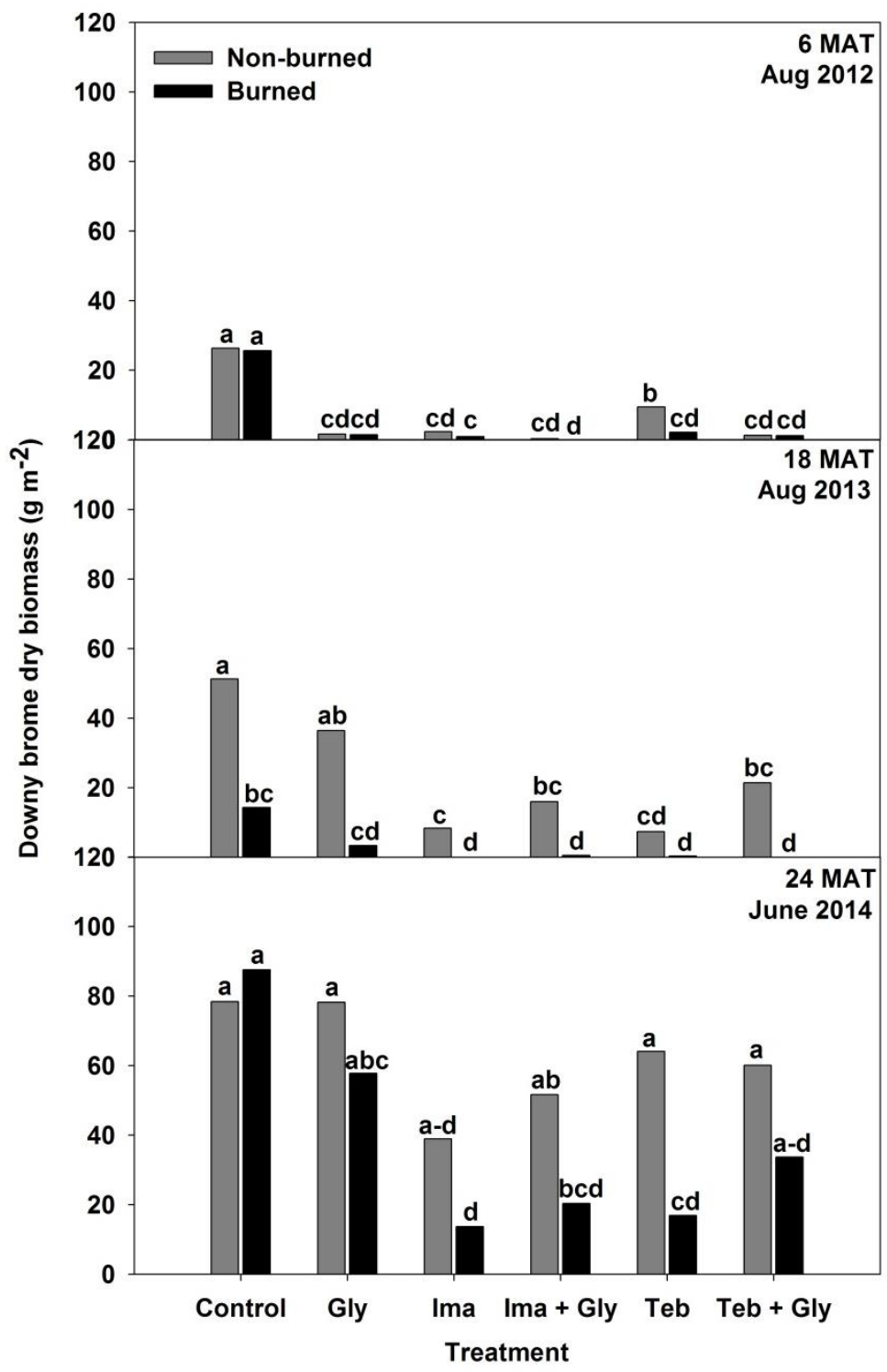

Figure 1.3: Downy brome biomass collected 6, 18 and 27 months after herbicide treatments were applied. Letters indicate differences among herbicide treatments within a burning treatment and within the data collection time point $(\mathrm{P}<0.05)$. Herbicide treatment abbreviations and rates are as follows: Gly (glyphosate $208 \mathrm{~g} \cdot \mathrm{ae} \cdot \mathrm{ha}^{-1}$ ), Ima (imazapic $105 \mathrm{~g} \cdot \mathrm{ai} \cdot \mathrm{ha}^{-1}$ ), Ima + Gly (imazapic $105 \mathrm{~g} \cdot \mathrm{ai} \cdot \mathrm{ha}^{-1}+$ glyphosate $208 \mathrm{~g} \cdot \mathrm{ae} \cdot \mathrm{ha}^{-1}$ ), Teb (tebuthiuron $420 \mathrm{~g} \cdot \mathrm{ai} \cdot \mathrm{ha}^{-1}$ ), Teb + Gly (tebuthiuron $420 \mathrm{~g} \cdot \mathrm{ai} \cdot \mathrm{ha}^{-1}+$ glyphosate $\left.208 \mathrm{~g} \cdot \mathrm{ae} \cdot \mathrm{ha}^{-1}\right) .($ Mean $[\mathrm{n}=8])$ 


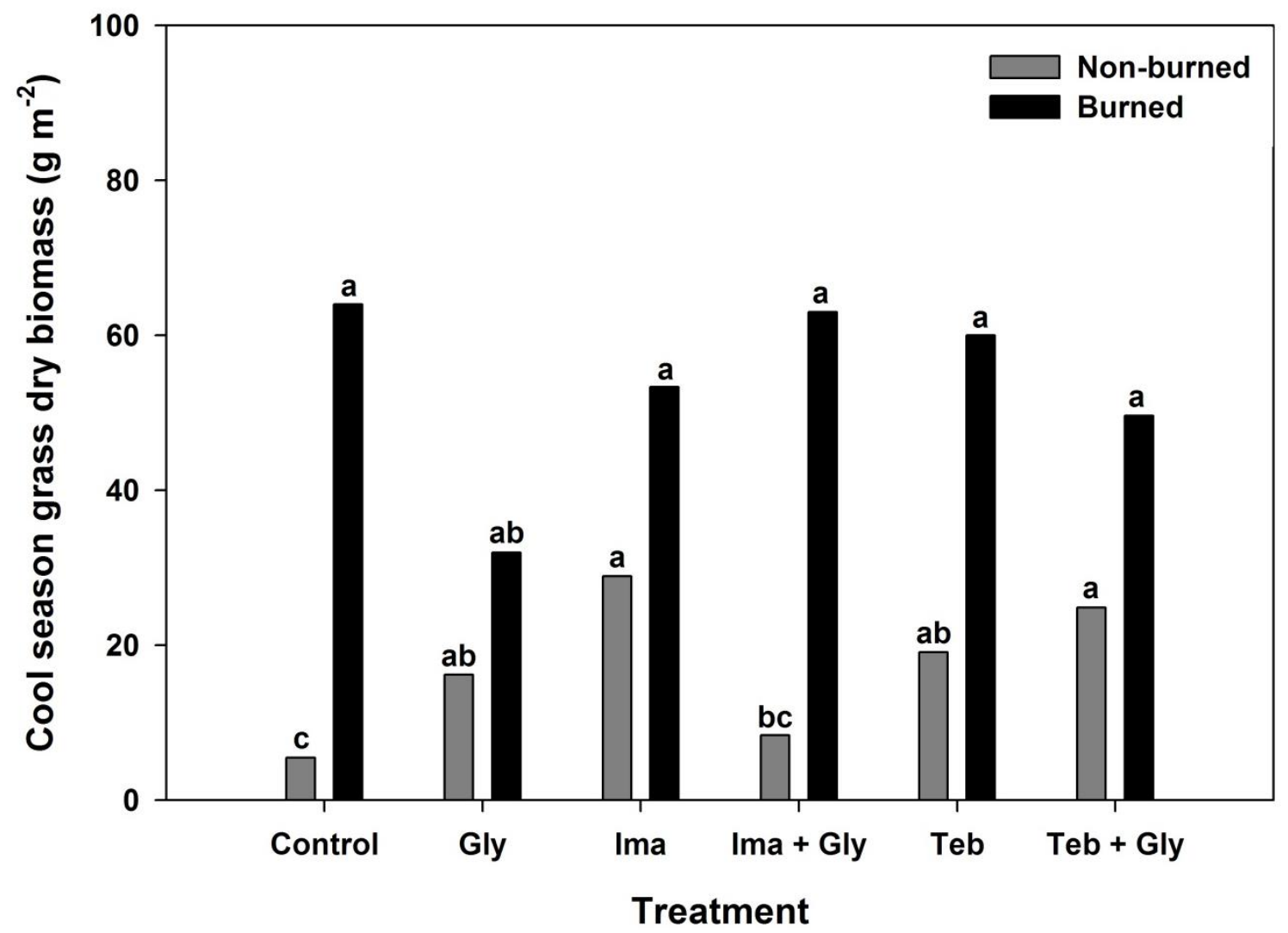

Figure 1.4: Native perennial cool season grass biomass averaged over the 6 and 18 month after herbicide treatment data collection time points. Different letters indicate differences among means $(\mathrm{P}<0.05)$. Herbicide treatment abbreviations and rates are as follows: Gly (glyphosate $208 \mathrm{~g} \cdot \mathrm{ae} \cdot \mathrm{ha}^{-1}$ ), Ima (imazapic $105 \mathrm{~g} \cdot \mathrm{ai} \cdot \mathrm{ha}^{-1}$ ), Ima + Gly (imazapic $105 \mathrm{~g} \cdot \mathrm{ai} \cdot \mathrm{ha}^{-1}+$ glyphosate 208 $\mathrm{g} \cdot \mathrm{ae} \cdot \mathrm{ha}^{-1}$ ), Teb (tebuthiuron $420 \mathrm{~g} \cdot \mathrm{ai} \cdot \mathrm{ha}^{-1}$ ), Teb + Gly (tebuthiuron $420 \mathrm{~g} \cdot \mathrm{ai} \cdot \mathrm{ha}^{-1}+\mathrm{glyphosate}$ $\left.208 \mathrm{~g} \cdot \mathrm{ae} \cdot \mathrm{ha}{ }^{-1}\right) .($ Mean $[\mathrm{n}=8])$ 


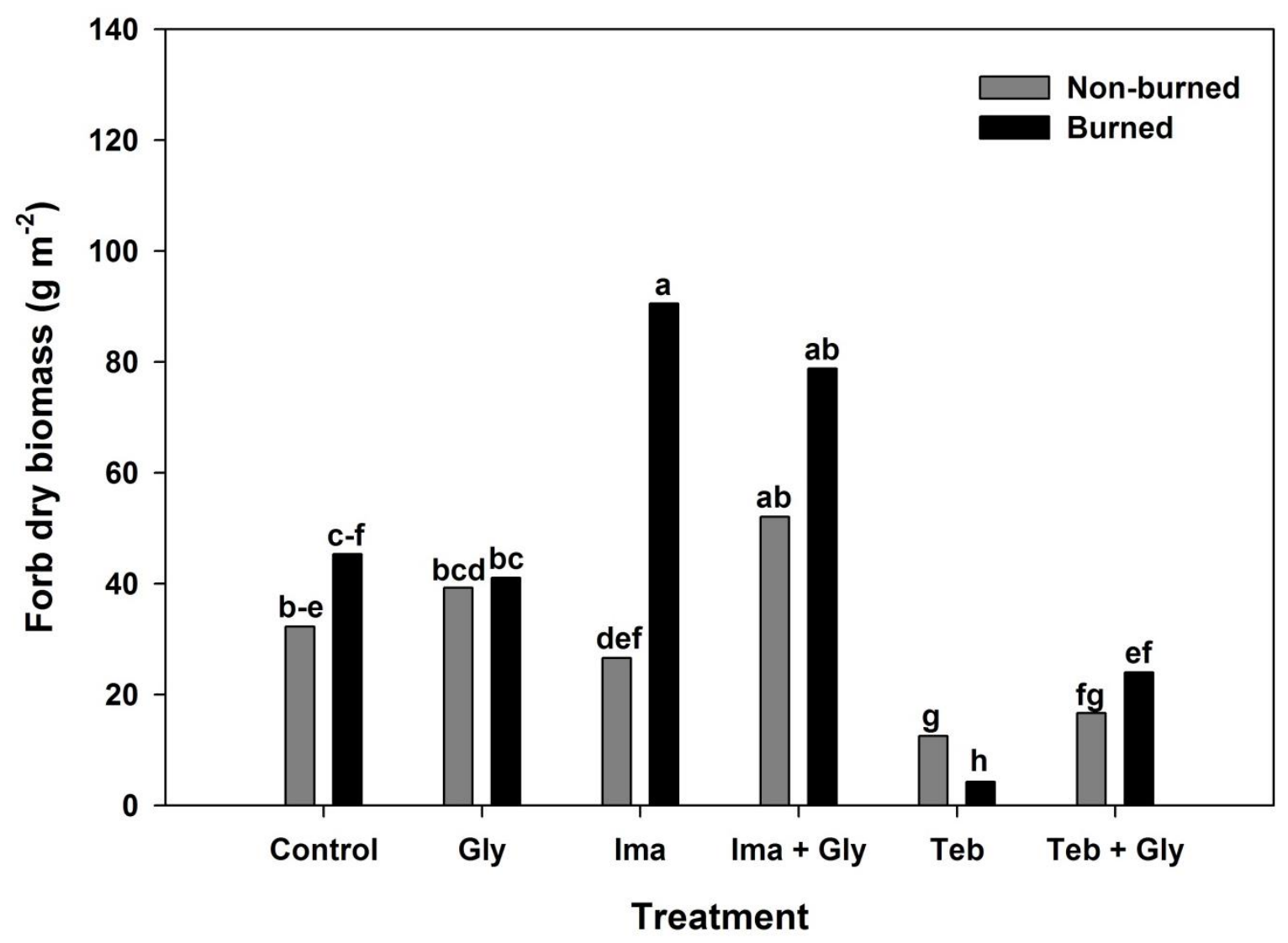

Figure 1.5: Native forb biomass averaged over the 6 and 18 month after herbicide treatment data collection time points. Different letters indicate differences among means $(\mathrm{P}<0.05)$. Herbicide treatment abbreviations and rates are as follows: Gly (glyphosate $208 \mathrm{~g} \cdot \mathrm{ae} \cdot \mathrm{ha}^{-1}$ ), Ima (imazapic $105 \mathrm{~g} \cdot \mathrm{ai} \cdot \mathrm{ha}^{-1}$ ), Ima + Gly (imazapic $105 \mathrm{~g} \cdot \mathrm{ai} \cdot \mathrm{ha}^{-1}+\mathrm{glyphosate} 208 \mathrm{~g} \cdot \mathrm{ae} \cdot \mathrm{ha}^{-1}$ ), Teb (tebuthiuron $420 \mathrm{~g} \cdot \mathrm{ai} \cdot \mathrm{ha}^{-1}$ ), Teb + Gly (tebuthiuron $420 \mathrm{~g} \cdot \mathrm{ai} \cdot \mathrm{ha}^{-1}+$ glyphosate $208 \mathrm{~g} \cdot \mathrm{ae} \cdot \mathrm{ha}^{-1}$ ). $($ Mean $[\mathrm{n}=8])$ 


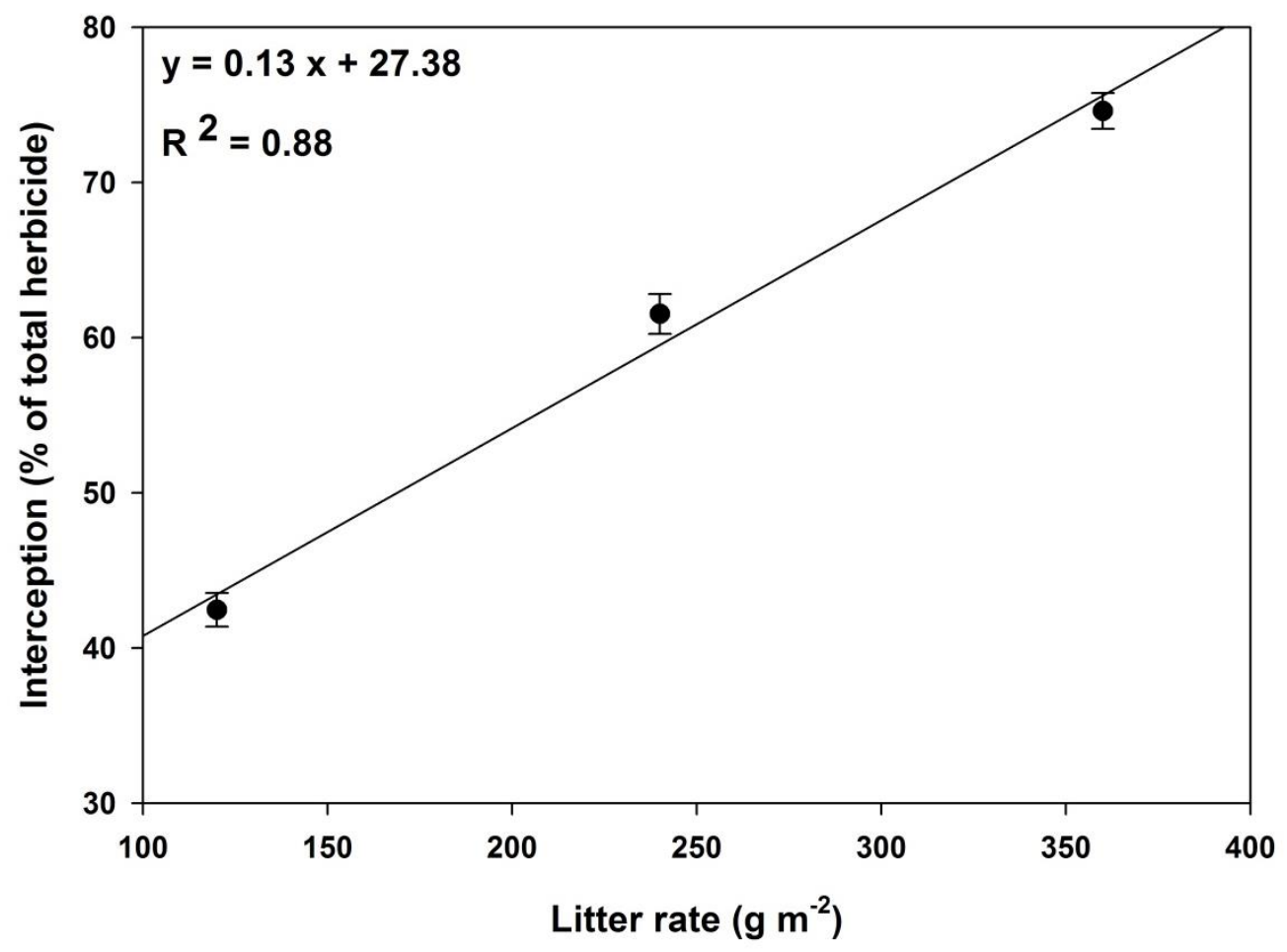

Figure 1.6: Data points represent the amount of imazapic and tebuthiuron that was intercepted by surface litter, as a percentage of total herbicide applied, at three litter amounts $(120,240$, and $360 \mathrm{~g} \cdot \mathrm{m}^{-2}$ ). The line shows the positive linear relationship between litter amount and the percentage of herbicide intercepted by surface litter. The highest litter amount is similar to the amount of surface litter reported within a dense downy brome infestation (Uresk et al. 1979). (Means \pm SE $[\mathrm{n}=16])$ 


\section{CHAPTER 1 REFERENCES}

Adair, E. C., I. C. Burke, and W. K. Lauenroth. 2008. Contrasting effects of resource availability and plant mortality on plant community invasion by Bromus tectorum L. Plant and Soil 304:103-115.

Bansal, S., R. L. Sheley, B. Blank, and E. A. Vasquez. 2014. Plant litter effects on soil nutrient availability and vegetation dynamics: changes that occur when annual grasses invade shrub-steppe communities. Plant Ecology 215:367-378.

Beck, K. G., J. R. Sebastian, and P. L. Chapman. 1995. Jointed goatgrass (Aegilops cylindrica) and downy brome (Bromus tectorum) control in perennial grasses. Weed Technology 9:255-259.

Beran, D. D., R. E. Gaussoin, and R. A. Masters. 1999. Native wildflower establishment with imidazolinone herbicides. HortScience 34:283-286.

Blumenthal, D. M., U. Norton, J. D. Derner, and J. D. Reeder. 2006. Long-term effects of tebuthiuron on Bromus tectorum. Western North American Naturalist 66:420-425.

Brooks, M. L. 2002. Peak fire temperatures and effects on annual plants in the mojave desert. Ecological Applications 12:1088-1102.

Burnside, O. C., R. G. Wilson, S. Weisberg, and K. G. Hubbard. 1996. Seed longevity of 41 weed species buried 17 years in eastern and western Nebraska. Weed Science 44:74-86.

Calo, A., S. Brause, and S. Jones. 2012. Integrated treatment with a prescribed burn and postemergent herbicide demonstrates initial success in managing cheatgrass in a northern Colorado natural area. Natural Areas Journal 32:300-304.

D'Antonio, C. M., and P. M. Vitousek. 1992. Biological invasions by exotic grasses, the grass/fire cycle, and global change. Annual Review of Ecology and Systematics 23:63-87. 
Daubenmire, R. 1968. Ecology of fire in grasslands. Advances in Ecological Research 5:209266.

Davies, K. W., and R. L. Sheley. 2011. Promoting native vegetation and diversity in exotic annual grass infestations. Restoration Ecology 19:159-165.

Davison, J. C., and E. G. Smith. 2007. Imazapic provides 2-year control of weedy annuals in a seeded Great Basin fuelbreak. Native Plants Journal 8:91-96.

Devine, R. 1993. The cheatgrass problem. Atlantic 271:40-45.

DiTomaso, J. M., M. L. Brooks, E. B. Allen, R. Minnich, P. M. Rice, and G. B. Kyser. 2006. Control of invasive weeds with prescribed burning. Weed Technology 20:535-548.

Duncan, C., M. Halstvedt, V. Peterson, and B. Sleugh. 2009. Comparing efficacy of various herbicides for downy brome control on western rangelands. In: T. R. J. Campbell (ed.), Proceedings of the Western Society of Weed Science; Albuquerque, NM, USA: Western Society of Weed Science. p. p. 44-45.

Duncan, C. A., J. J. Jachetta, M. L. Brown, V. F. Carrithers, J. K. Clark, J. M. DiTomaso, R. G. Lym, K. C. McDaniel, M. J. Renz, and P. M. Rice. 2004. Assessing the economic, environmental, and societal losses from invasive plants on rangeland and wildlands. Weed Technology 18:1411-1416.

Elseroad, A. C., and N. T. Rudd. 2011. Can imazapic increase native species abundance in cheatgrass (Bromus tectorum) invaded native plant communities? Rangeland Ecology \& Management 64:641-648.

Evans, R. A., and J. A. Young. 1970. Plant litter and establishment of alien annual weed species in rangeland communities. Weed Science 18:697-703. 
Hardegree, S. P., J. M. Schneider, and C. A. Moffet. 2012. Weather variability and adaptive management for rangeland restoration. Rangelands 34:53-56.

Harper, J., J. Williams, and G. Sagar. 1965. The behaviour of seeds in soil: I. The heterogeneity of soil surfaces and its role in determining the establishment of plants from seed. The Journal of Ecology 53:273-286.

Keeley, J. E., and T. W. McGinnis. 2007. Impact of prescribed fire and other factors on cheatgrass persistence in a Sierra Nevada ponderosa pine forest. International Journal of Wildland Fire 16:96-106.

Knapp, A., and T. Seastedt. 1986. Detritus accumulation limits productivity of tallgrass prairie. Bioscience 36:662-668.

Knapp, P. A. 1996. Cheatgrass (Bromus tectorum 1.) dominance in the great basin desert: History, persistence, and influences to human activities. Global Environmental Change $6: 37-52$

Kyser, G. B., J. M. DiTomaso, M. P. Doran, S. B. Orloff, R. G. Wilson, D. L. Lancaster, D. F. Lile, and M. L. Porath. 2007. Control of medusahead (Taeniatherum caput-medusae) and other annual grasses with imazapic. Weed Technology 21:66-75.

Kyser, G. B., R. G. Wilson, J. Zhang, and J. M. DiTomaso. 2013. Herbicide-assisted restoration of Great Basin Sagebrush Steppe infested with medusahead and downy brome. Rangeland Ecology and Management 66:588-596.

Link, S. O., C. W. Keeler, R. W. Hill, and E. Hagen. 2006. Bromus tectorum cover mapping and fire risk. International Journal of Wildland Fire 15:113-119.

Lym, R. G., and D. R. Kirby. 1991. Effect of glyphosate on introduced and native grasses. Weed Technology 5:421-425. 
Mack, R. N. 1981. Invasion of Bromus tectorum L. into western North America: An ecological chronicle. Agro-ecosystems 7:145-165.

Mangold, J., H. Parkinson, C. Duncan, P. Rice, E. Davis, and F. Menalled. 2013. Downy brome (Bromus tectorum) control with imazapic on Montana grasslands. Invasive Plant Science and Management 6:554-558.

Masters, R. A., S. J. Nissen, R. E. Gaussoin, D. D. Beran, and R. N. Stougaard. 1996. Imidazolinone herbicides improve restoration of Great Plains grasslands. Weed Technology 10:392-403.

Melgoza, G., R. S. Nowak, and R. J. Tausch. 1990. Soil water exploitation after fire: competition between Bromus tectorum (cheatgrass) and two native species. Oecologia 83:7-13.

Monaco, T. A., T. M. Osmond, and S. A. Dewey. 2005. Medusahead control with fall-and spring-applied herbicides on Northern Utah Foothills. Weed Technology 19:653-658.

Morris, C., T. A. Monaco, and C. W. Rigby. 2009. Variable impacts of imazapic rate on downy brome (Bromus tectorum) and seeded species in two rangeland communities. Invasive Plant Science and Management 2:110-119.

Morrow, L., C. Fenster, and M. McCarty. 1977. Control of downy brome on Nebraska rangeland. Journal of Range Management 30:293-296.

Morrow, L. A., and P. W. Stahlman. 1984. The history and distribution of downy brome (Bromus tectorum) in North America. Weed Science 32:2-6.

NCWCD. 2014. Weather and Evapotraspiration Data. Available at: http://www.northernwater.org/waterconservation/weatherandetdata.aspx. Accessed 5 June 2014. 
NOAA. 2013. Historic Rainfall and Floods in Colorado. Available at: http://www.climate.gov/news-features/event-tracker/historic-rainfall-and-floodscolorado. Accessed 10 September 20142014.

Ogle, S. M., W. A. Reiners, and K. G. Gerow. 2003. Impacts of exotic annual brome grasses (Bromus spp.) on ecosystem properties of northern mixed grass prairie. The American midland naturalist 149:46-58.

Rinella, M. J., R. A. Masters, and S. E. Bellows. 2010. Growth regulator herbicides prevent invasive annual grass seed production under field conditions. Rangeland Ecology \& Management 63:487-490.

SAS Institute. 2010. SAS/STAT 9.3 user's guide. Version 5. Cary, NC, USA: SAS Institute, Inc.

Senseman, S. A. 2007. Herbicide Handbook. Lawrence, KS, USA: Weed Science Society of America.

Sheley, R. L., M. F. Carpinelli, and K. J. R. Morghan. 2007. Effects of imazapic on target and nontarget vegetation during revegetation. Weed Technology 21:1071-1081.

Shinn, S. L., and D. C. Thill. 2004. Tolerance of several perennial grasses to imazapic. Weed Technology 18:60-65.

Uresk, D. W., J. F. Cline, and W. H. Rickard. 1979. Growth rates of a cheatgrass community and some associated factors. Journal of Range Management 32:168-170.

USDA-NRCS. 2014. Web soil survey. Available at: http://websoilsurvey.nrcs.usda.gov/app/. Accessed 5 June 2014.

Washburn, B. E., T. G. Barnes, and J. D. Sole. 1999. No-till establishment of native warmseason grasses in tall fescue fields first-year results indicate value of new herbicide. Ecological Restoration 17:144-149. 
Whitson, T. D., M. A. Ferrell, and H. P. Alley. 1988. Changes in rangeland canopy cover seven years after tebuthiuron application. Weed Technology 2:486-489.

Whitson, T. D., and D. W. Koch. 1998. Control of downy brome (Bromus tectorum) with herbicides and perennial grass competition. Weed Technology 12:391-396.

Young, J. A., and F. L. Allen. 1997. Cheatgrass and range science: 1930-1950. Journal of Range Management 50:530-535.

Young, J. A., R. A. Evans, and R. E. Eckert, Jr. 1969. Population dynamics of downy brome. Weed Science 17:20-26.

Young, J. A., R. A. Evans, and R. A. Weaver. 1976. Estimating potential downy brome competition after wildfires. Journal of Range Management 29:322-325. 
Appendix 1: Imazapic and Tebuthiuron Pre-emergent Dose Response Experiment 
The Plateau ${ }^{\circledR}$ label states that downy brome (Bromus tectorum L.) is controlled when 4 to $6 \mathrm{oz}$ product per acre or 70 to $105 \mathrm{~g} \cdot \mathrm{ai} \cdot \mathrm{ha}^{-1}$ are applied pre-emergent (PRE)(Anonymous 2011); however, a study evaluating the results of several field studies throughout Montana reported PRE as the least efficacious timing (Mangold et al. 2013). This discrepancy prompted us to conduct a PRE dose response greenhouse experiment. We included tebuthiuron as a treatment because, to our knowledge, no studies evaluating tebuthiuron to control downy brome PRE have been published.

Downy brome seed was collected from a rangeland research property owned by Colorado State University (CSU) (lat 4042’36”N, long 1056’36”W) in July, 2013. Soil was collected in June of 2014 from a CSU agricultural property (Agricultural Research Development \& Education Center, lat $40^{\circ} 38^{\prime} 60^{\prime \prime} \mathrm{N}$, long $105^{\circ} 0^{\prime} 0^{\prime \prime} \mathrm{W}$ ) and passed through a $2.8 \mathrm{~mm}$ sieve. Two composite samples were collected from the top $20 \mathrm{~cm}$ of soil and air dried for $24 \mathrm{~h}$ before sending subsamples to a private lab for general analysis (Ward Laboratories, Inc). Nine seeds were planted per pot $(8.5 \times 8.5 \times 7 \mathrm{~cm})$ and covered with $1 \mathrm{~cm}$ of sieved soil. Herbicide was applied to pots after planting using an overhead track spray chamber (DeVries Manufacturing Corp) with a single flat fan $8002 \mathrm{E}$ nozzle (TeeJet, Tech), calibrated to apply $187 \mathrm{~L} \cdot \mathrm{ha}^{-1}$ at 172 $\mathrm{kPa}$ (TeeJet, Tech). Imazapic was applied at $0,2,3,7,14,26,53,105$, and $210 \mathrm{~g} \cdot \mathrm{ai} \cdot \mathrm{ha}^{-1}$, while tebuthiuron was applied at $0,13,26,53,105,210,420,841$, and $1680 \mathrm{~g} \cdot$ ai $\mathrm{ha}^{-1}$. Herbicide was incorporated by applying $10 \mathrm{~mm}$ rainfall using an 8004E nozzle (TeeJet Tech) traveling at 1.2 $\mathrm{km} \cdot \mathrm{h}^{-1}$ (TeeJet Tech). Treated pots were transferred to a growth chamber and watered twice daily. The growth chamber was set at $20 \mathrm{C}$ with a $12 \mathrm{~h}$ photoperiod supplied by photosynthetic photon flux (PPF) of $400 \mu \mathrm{mol} \cdot \mathrm{m}^{-2} \cdot \mathrm{s}^{-1}$ (Cenviron E-15, Pembina, ND). Twenty-eight DAT all plants within each pot were counted and shoot biomass was collected. The fresh tissue was 
weighed and then dried in a $60 \mathrm{C}$ oven for $24 \mathrm{~h}$ to determine dry weights. The experiment was a completely randomized design, each pot was a separate treatment and each treatment was replicated three times. The entire experiment was repeated.

Data were analyzed using an ANOVA model and nonlinear regression model in PROC GLM and PROC NLIN (SAS Institute 2010). An ANOVA was conducted to ensure that herbicide dose was a predictor of dry biomass before conducting a logistic analysis with dose as a predictor of the relative dry biomass as percentage of control (Seefeldt et al. 1995). Regression models were used to determine the dose at which $50 \%$ growth reduction $\left(\mathrm{GR}_{50}\right)$ occurs. The model was constructed using equation one.

$$
y=b * \log (\text { dose })+a
$$

Soil analysis indicated that the $\mathrm{pH}$ was $7.6, \mathrm{OM}$ was $2.4 \%$, and CEC (meq $100 \mathrm{~g}^{-1}$ ) was 36.7. The soil was classified as clay, with $32 \%$ sand, $25 \%$ silt and $43 \%$ clay. The $\mathrm{GR}_{50}$ for imazapic was $3 \mathrm{~g} \cdot \mathrm{ai} \cdot \mathrm{ha}^{-1}$ or $3 \%$ of the dose applied in the field study. Based on the dose response curve, we are $95 \%$ confident that this dose will cause a growth reduction in total biomass between 45 to $58 \%$ following a PRE application (Fig. 2.1). Tebuthiuron does not appear to be as biologically active as imazapic. The $\mathrm{GR}_{50}$ for tebuthiuron was calculated at 57 g. ai $\cdot$ ha $^{-1}$ with a $95 \%$ CI ranging from 42 to $61 \%$ (Fig. 2.1). At the highest herbicide dose for tebuthiuron a $100 \%$ reduction in biomass occurred; however, for imazapic, $4 \%$ of biomass was remaining 28 DAT, even at the highest dose of herbicide. The $\mathrm{GR}_{50}$ for imazapic and tebuthiuron were most accurately predicted by equation two and three, respectively.

$$
\begin{aligned}
& y=-18.95 * \log (\text { dose })+50.51 \\
& y=-24.60 * \log (\text { dose })+71.95
\end{aligned}
$$


These $\mathrm{GR}_{50}$ values are much lower than recommended field rates. Although we are confident that the tested biotype can be successfully controlled with PRE applications of both herbicides, other studies have reported PRE as the least efficacious timing (Mangold et al. 2013). Before determining management implications based on our greenhouse dose response experiment, we believe differences between biotypes should be examined. 

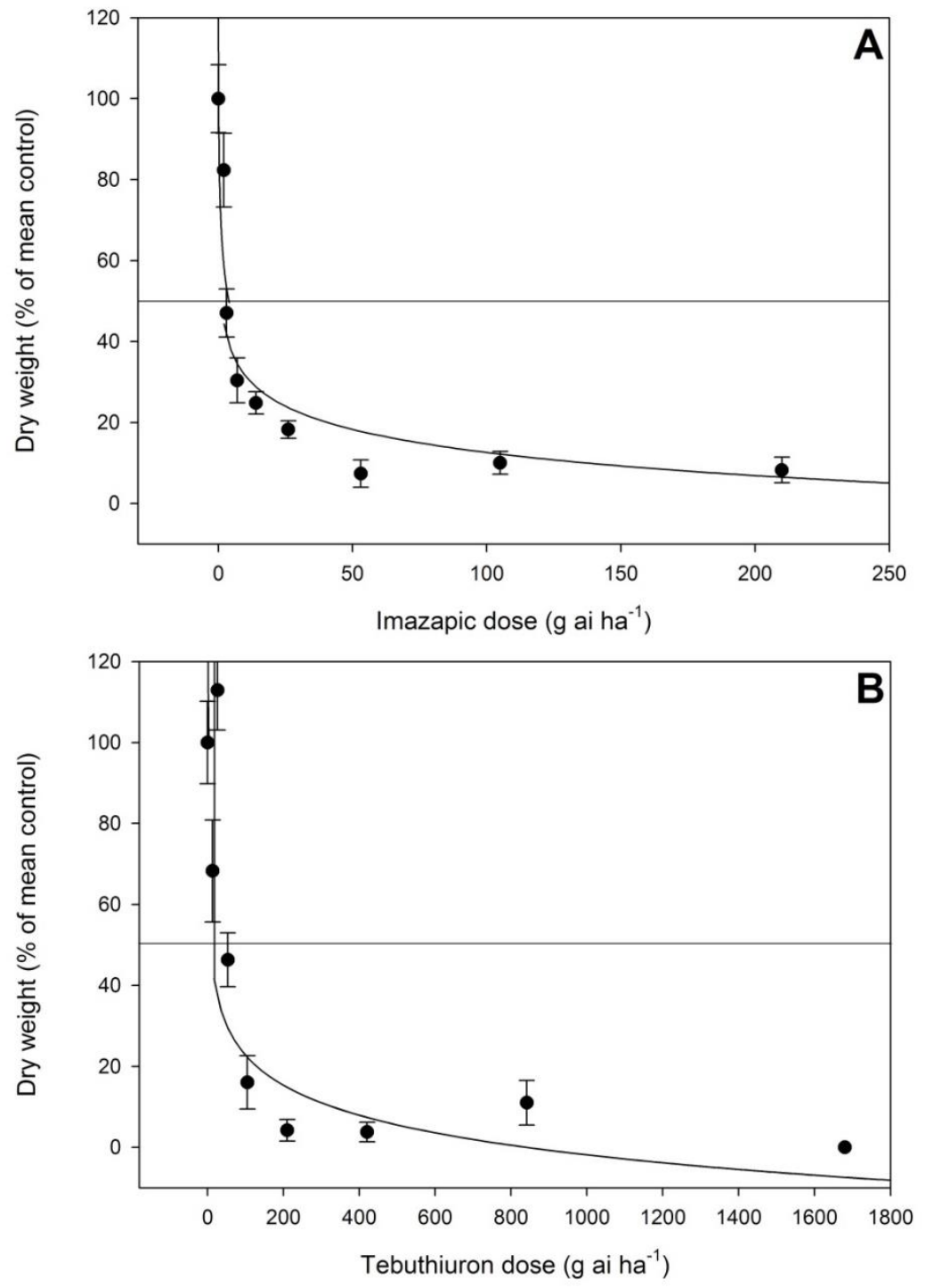

Figure A1.1: Response of downy brome dry weight to various imazapic (A) and tebuthiuron (B) doses, 28 days after treatment. Treatments were applied pre-emergent and conducted in the greenhouse. Means are expressed as a percentage of the control mean. All curves were calculated using the logistic equation: $y=b * \log ($ dose $)+a$. $\mathrm{GR}_{50}$ values were calculated to be $3 \mathrm{~g} \cdot \mathrm{ai} \cdot \mathrm{ha}^{-1}$ for imazapic (A) and $57 \mathrm{~g} \cdot \mathrm{ai} \cdot \mathrm{ha}^{-1}$ for tebuthiuron $(\mathbf{B})$. The horizontal line represents the $\mathrm{GR}_{50}$. $($ Mean $\pm \mathrm{SE}[\mathrm{n}=6])$. 


\section{APPENDIX 1 REFERENCES}

Anonymous. 2011. Plateau ${ }^{\circledR}$ herbicide product label. BASF Publication. No. NVA 2011-04-1260007. Research Triangle Park, NC: BASF. 15 p

Mangold, J., H. Parkinson, C. Duncan, P. Rice, E. Davis, and F. Menalled. 2013. Downy brome (Bromus tectorum) control with imazapic on Montana grasslands. Invasive Plant Science and Management 6:554-558.

SAS Institute. 2010. SAS/STAT 9.3 user's guide. Version 5. Cary, NC, USA: SAS Institute, Inc.

Seefeldt, S. S., J. E. Jensen, and E. P. Fuerst. 1995. Log-logistic analysis of herbicide doseresponse relationships. Weed Technology 9:218-227. 
Appendix 2: Imazapic and Tebuthiuron Litter Interception Experiment 
Our conclusions from Chapter 1 suggest that herbicide is intercepted on surface litter, and remains sorbed until a precipitation event occurs; however, due to persistent drought, land managers may not have the opportunity to apply herbicides before a timely precipitation event. We conducted a greenhouse study to determine the impact of interception on herbicide efficacy when a precipitation event does not rinse the herbicide from the litter after a pre-emergent (PRE) application. We hypothesized that as litter amount and herbicide interception increased, herbicide efficacy would decrease.

Downy brome seed source and soil collection followed the protocols outlined in Appendix 1. (For soil analysis results, see Appendix 1). Pots (26 X 26 X $6 \mathrm{~cm}$ ) were filled with field soil that had been mixed with $10 \mathrm{~g}$ of $19-6$ - 12 osmocote fertilizer (The Scott's Company, Marysville, $\mathrm{OH}$ ) before sowing 6 rows of 5 seeds each. Seeds were then covered with approximately $1 \mathrm{~cm}$ of field soil. Before herbicide application, litter was spread evenly over the soil surface. For litter collection and preparation methods please refer to Chapter 1, "Herbicide Sorption to Litter." Five litter amounts $\left(55,122,256,390,524 \mathrm{~g} \cdot \mathrm{m}^{-2}\right)$ were included in this experiment. Litter amounts were hypothesized to intercept approximately 20, 40, 60, 80 and $100 \%$ of the applied herbicide as determined using the equation displayed in Chapter 1, Figure 6. To confirm the actual percentage of herbicide intercepted by these litter amounts, we followed the "Herbicide Sorption to Litter: Interception" and "Herbicide Sorption to Litter: Highperformance Liquid Chromatography Analysis" protocols from Chapter 1. After litter placement, herbicides were applied using an overhead track spray chamber (DeVries Manufacturing Corp) with a single flat fan 8002E nozzle (TeeJet Tech), calibrated to apply 187 $\mathrm{L} \cdot \mathrm{ha}^{-1}$ at $172 \mathrm{kPa}$. Application rates were $105 \mathrm{~g} \cdot \mathrm{ai} \cdot \mathrm{ha}^{-1}$ and $210 \mathrm{~g} \cdot \mathrm{ai} \cdot \mathrm{ha}^{-1}$ for imazapic and tebuthiuron, respectively. Ten minutes after herbicide application, litter was removed from the 
soil surface. After litter removal, pots received $5 \mathrm{~mm}$ of simulated rainfall, using the same spray chamber with an $8004 \mathrm{E}$ nozzle traveling at $1.2 \mathrm{~km} \cdot \mathrm{h}^{-1}$ (TeeJet Tech) to incorporate herbicide not intercepted by litter and stimulate seed germination. Pots were then transferred to the greenhouse and sub-irrigated as needed to maintain plant growth. The greenhouse had a $12 \mathrm{~h}$ day length, maintained by overhead, 400-watt, sodium halide lamps and temperature varied between 24 and $18 \mathrm{C}$ throughout the experiment. Plants remained in the greenhouse for $28 \mathrm{~d}$ before shoot biomass was collected. Biomass samples were dried at $60 \mathrm{C}$ for $72 \mathrm{~h}$ before dry weight was determined. Interception data and biomass data were analyzed using PROC REG and PROC NLIN, respectively (SAS Institute 2010).

Confirming the results of our previous interception experiment (Chapter 1, Fig. 6), the percentage of herbicide intercepted by litter had a positive, linear relationship to litter amount $\left(\mathrm{R}^{2}=0.8830\right)$ (Fig. 3.1). Additionally, we found no difference between the interception of imazapic or tebuthiuron $(\mathrm{p}=0.7322)$. At the highest litter amount, $525 \mathrm{~g} \cdot \mathrm{m}^{-2}$, only $88 \%$ of herbicide was intercepted by the litter. Based on the linear regression equation determined by the previous interception experiment, we had expected this litter amount to intercept approximately $100 \%$ of the herbicide. We believe that this inconsistency is due to a flaw in our experimental design. The manner in which we placed litter over both the pots and metal pan allowed a small amount of herbicide to enter around the edges of each sprayed metal pan.

Downy brome susceptibility to imazapic and tebuthiuron was most accurately predicted by equation one and two, respectively (Fig 3.1).

$$
\begin{aligned}
& y=2.62 * e^{0.00391 *(\text { litter amount })} \\
& y=15.66 * e^{0.00213 *(\text { litter amount })}
\end{aligned}
$$


Based on the interception experiment, $12 \%$ of the herbicide was not intercepted by litter at the highest amount and applied directly to the soil surface. This amount was higher than the $\mathrm{GR}_{50}$ for imazapic and close to the $\mathrm{GR}_{50}$ for tebuthiuron, as determined in Appendix 1. During data collection it was apparent that downy brome seedling in high litter treatments were showing symptoms of herbicide injury and that herbicide efficacy was only marginally affected by litter amount. The population of downy brome used in these experiments appears to be highly susceptible to low doses of imazapic and tebuthiuron, when applied PRE. Determining whether these herbicides are more readily absorbed by shoots or roots may help determine whether a PRE or POST application timing is most efficacious. In addition, it is possible that downy brome biotypes may have varying susceptibility to both of these herbicides. Future studies evaluating individual biotype sensitivity to these herbicides could be beneficial to determine if different biotypes have various sensitivities to these herbicides. 


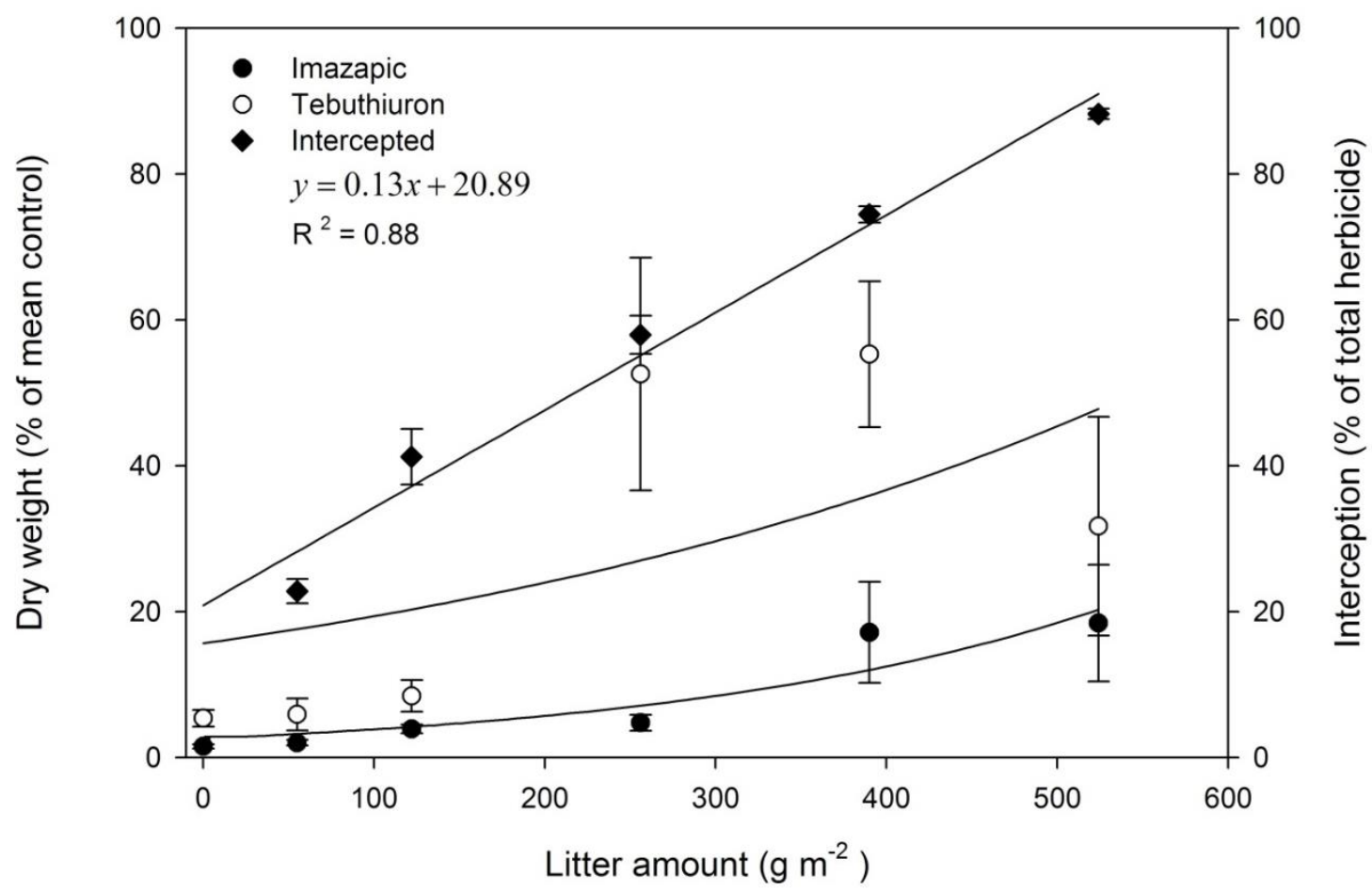

Figure A2.1: The left axis shows the response of downy brome dry weight to imazapic and tebuthiuron when application occurred over various litter amounts, 28 days after treatment. Treatments were applied pre-emergent and litter was removed after application. The right axis shows the amount of imazapic and tebuthiuron that was intercepted by surface litter, as a percentage of total applied herbicide. Litter amounts for both axes included 55, 122, 256, 390 and $524 \mathrm{~g} \cdot \mathrm{m}^{-2}$. The line shows the positive linear relationship between litter amount and percentage of herbicide intercept. Means are expressed as a percentage of the control mean. Imazapic and tebuthiuron curves were calculated using the exponential equation: $y=b *$ $e^{a(\text { litter amount })}$ and the linear equation representing herbicide interception was calculated using the equation: $y=b *($ litter amount $)+a($ Mean $\pm \operatorname{SE}[\mathrm{n}=4])$. 


\section{APPENDIX 2 REFERENCES}

SAS Institute. 2010. SAS/STAT 9.3 user's guide. Version 5. Cary, NC, USA” SAS Institute, Inc. 